DOI: 10.20472/TEC.2019.008.006

FERNANDO DE ROSA

Independent Researcher, Brazil

\author{
BENTO ALVES DA COSTA FILHO \\ UNIALFA, Brazil
}

JOSE GASPAR NAYME NOVELLI

IESB Mestrado, Brazil

\title{
STUDENT GLOBALIZATION: HOW MUCH INTERNATIONALIZED ARE BRAZILIAN MBA STUDENTS? A MEASUREMENT PROPOSITION
}

\begin{abstract}
:
The supply and demand for MBA courses have grown over time worldwide. The most diversified programs are available at business schools. The opportunity for exchange experiences and establish international network has stood out among the students' priorities. This paper seeks to build a research model that would permit the assessment of Brazilian MBA students about the internationalization of their career and academic life as a consequence or due to an MBA Course. Global mindset driven to an internationalized behavior can be expressed by the conversion among experiences abroad and internationalization at home tied with global global skills. A model with multidimensional factors is proposed after a comprehensive examination of the literature. This model is composed by four constructs: internationalization at home, experience abroad, global skills and global mindset. Although literature presents the above constructs isolated or partially combined, none of them bring a model integrating all of them or considering higher education in a holistic approach. The study developed by McCormick \& Stephen (2016) was used as a basis for the present model construction, which improves this lack of integration approach. This research model would permit the identification of the main factors that explain the likelihood to be an internationalized MBA student.
\end{abstract}

\section{Keywords:}

MBA, internationalization, career, business school, global mindset, global skills

JEL Classification: 123 


\section{Introduction}

Considering the students point of view, recent surveys indicate they have common expectations about higher education in business. According to international research available at Statista (2015) website, the main reasons mentioned by students to do an MBA course are related to the possibilities of improving the career, acquiring new abilities, obtaining leadership positions and building professional networks. As a confirmation of these expectations, a poll conducted by the Association of International Graduate Admissions Consultants (AIGAC), with 1,377 MBA candidates in the USA, found out as very important the acquisition of professional traits linked to new abilities/knowledge, and the new possibilities in terms of career perspectives (Ozbilgin et al. 2004; Hay \& Hodgkinson 2006; Dhanawade \& Sarang 2012; Byrne 2018).

In Brazil, Vasquez \& Ruas (2012), in an survey with 160 students from six higher education programs, in the period of 2004 to 2008, had as results that the strengths of MBA courses are due to the fact that students have the opportunity to combine knowledge, capacities and competencies which prepare them to deal with daily challenges at work. This study did not aim to demonstrate the relationship between job challenges and career abroad. According the authors, the way that MBA students rethink practices depends on their active responses to the subjects and experiences faced in MBA educational contexts, which could be a minimum level of competencies to work abroad.

Taking into consideration that MBAs should contribute to prepare the students to deal with professional obstacles and also that these challenges usually go beyond national frontiers, qualifying courses by incorporating international knowledge, savvy and experience for the learners would be a good alternative.

In Brazil, several MBA courses have been recently launched as an internationalized version that sometimes implies the students to stay abroad less than one month, in the middle or at the end of the course, and be back to complete their studies at the Brazilian school.

This kind of a short internship in a different country is aligned with some students' expectations that would contribute for their careers and network. However, insufficient basic educational background and bad performance on foreign languages for Brazilian students might limit initiatives and programs aiming at improving the potential learning for students to have global connectivity experiences.

This way, the main research question to be answered in this paper is: how much internationalized are MBA students in Brazil, considering that internationalization supposes to be a conversion among experiences abroad and at home tied with global mindset and skills?

From this questioning, the main objective of this article is to build a research model that would permit the assessment of MBA students about the internationalization of their career and academic life as a consequence or due to an MBA Course.

The literature review reports a considerable amount of research on relevant concepts related to the internationalization of higher education: internationalization of curriculum (Leask 2009; Clifford 2013), innovative pedagogic approaches (Simm \& Marvell 2017; Kenna 2017), intercultural, learning and personal experience (Gu 2009; Hudzik 2010; Lyones \& Gurholt 2017; Pereira et al. 2017), critical thinking (Scheunpflug 2011; Bourn 2014; Kenna 2017; Lehtomäki et al. 2017), cross cultural competence (Johnson et al. 2006; Griffith 2009), global thinking (Bourn 2014; Klein et al. 2014; McCormick \& Stephen 2016), the challenge of established knowledge (Clifford \& Montgomery, 2014; Killick 2015), global perspective 
(Hanvey 1976; Klein et al. 2014), global connectedness (Lehtomäki et al. 2017), global citizenship (Nussbaum 2002; Clifford \& Montgomery 2014; Haigh 2014; Sherman 2017), global dimension (Bourn 2014) and world-mindedness (Béneker et al. 2013).

Although the cited papers present those constructs isolated or partially combined, none of them bring a model integrating all of them. Therefore, there is a lack of studies considering the most important concepts in internationalization of higher education in a holistic approach. Of the aforementioned references, the article with a more comprehensive line of thought is the one developed by McCormick \& Stephen (2016), considering the graduate students' perspective. Their paper will be taken as a basis for the exploration of the main constructs of the model we proposed ahead in the text.

Looking for the achievement of this objective, the paper was structured as follows: first, the expectations of MBA stakeholders and a picture of the MBA evolution were explored; second, the constructs related to the degree of internationalization of students were characterized; and third, the proposed model for evaluation of the global facet was depicted and discussed in its structure and relationships among variables.

It is noteworthy to highlight that it is not the scope of the paper the assessment of MBA courses curricula but to ascertain the perception of students about the contribution of these courses to the internationalization of their careers.

\section{Expectations of MBA Stakeholders and MBA Evolution}

The literature shows convergence in expectations of students, faculties and employers about the purpose of MBA courses. It is also relevant to check if the professional that participates in the MBA gather the necessary technical and managerial attributes to what Lehtomäki et al.(2017) named "global connectivity", i.e., minimum requirements that contribute to the generation of knowledge from the apprenticeship provided by the MBA - a knowledge that could transform the working environment.

Sharkey \& Beeman (2008) found out that technological change, globalization, and increased competition are the most important environmental challenges facing MBA programs today, mainly in technology-based competition.

Elliot \& Robinson (2011) interviewed 43 UK MBA students and confirmed the expectations of an international managerial imaginary, which means "international networks", "international knowledge and skills", "international prestige" and "intercultural debate". Tay (2001) also claims that employers expect more MBAs with the ability to understand local, Asian and global business practices in a survey of 118 organizations in Malaysia.

Balmant (2018) comments that "in an increasingly global world, where international experience weighs heavily, boost the curriculum with a international graduate degree can define a hiring opportunity, a job promotion or a high salary range." This may explain the increase in the number of Brazilians willing to study abroad, who could gain an opportunity to get a promotion or a new job.

To find out how are student's expectations about an MBA course, Cruz \& Wood Jr. (2013) conducted a survey with 700 graduate students at Fundação Getulio Vargas. The results suggested the expectations of students about an MBA course are concentrated in the possibilities of development of competences, exploration of management techniques, 
improvement of professional performance, upgrading of curriculum and enhancement of employability.

Veludo-de-Oliveira \& Ikeda (2006) identified that MBA students bring as value in educational services as the relationship among peers (networking) and an immediacy approach to learning. Silva \& Godoy (2016) investigated by means of in-depth interviews the perception of MBA students about the course, its learning and impacts on the career. Results keep connection with research findings aforementioned in this paper, i.e., students identified as fundamental points of a MBA: the practical approach, the amplified vision of the business complexity, the knowledge and lived experiences in the classroom that generate impacts in the working environment.

According Daniel (1998, apud Herrington 2010), 110 MBA degrees were conferred in 1910 and no more than 4,335 were awarded until 1949. However, between 1950 and 1975 the MBA underwent tremendous growth in the USA. The very first records of a business program in higher education were attributed to Harvard University: the institution offered a course to 59 graduate students in 1908. Today, MBA is one of the most popular graduate degree programs in the USA. However, the growth was not so fast. Since the first course, the number of MBA degrees conferred increased to over 40,000 per year and the number of MBA programs grew by approximately 500 (Daniel 1998, apud Herrington 2010).

Based on the Application Trends Survey Report 2018, it can be comprehended that MBA programs report a similar volume of applications in 2018 compared with 2017 (GMAC 2018). Despite this stability, numbers are different when visualized in a regional context, when US is slightly reducing the demand, in the other hand Europe and Canada are increasing it. If the MBA format is considered in the analysis, it can be seen that American Full Time 2-year MBA are reducing in more than $70 \%$ of the Programs that answer the survey.

However, the amount of GMAC applications during 2018 continues to be quite high, almost 300,000 candidates in 549 Programs that answer the survey in both last 2 years.

Since the beginning of the 1990s Brazil has experienced a profusion of MBA offerings (Ikeda et al. 2005) due to factors such as the low regulation of the Ministry of Education, academic deficiencies in Business School and lack of skills in workplace. Even today, part of the MBA students has partial and full subsidy from their employers. The Brazilian Guide of MBA, published by Folha de S. Paulo newspaper (Zaremba 2016), points out the need of "tropicalization" of MBAs, which are not considered a master's degree by the government but a lato sensu graduate course.

Sabbag (2017) approaches in a broader context, which applies to several postgraduate courses in Brazil, citing that "Graduate studies have become increasingly essential for successful career. The number of students enrolled in postgraduate courses in Brazil increased by over $100 \%$ in ten years, with the most recent data from 2015 showing that 325,230 students enrolled in postgraduate courses (Specialization, Master's, Doctorate and Post-doctorate), more than double that registered in 2005. During the same period, the number of courses also increased from 2,057 to 3,905.

Unlike the USA, Brazilian students do not count on public and private enforcement entities to follow up the courses performance like AACSB, Executive MBA Council, AMBA and EQUIS. 


\section{Internationalization of MBA}

There is consensus in the academy about the benefits of interconnectivity of the MBA students with the world as a whole. Recent research suggests trends of business schools toward the construction of programs based on labor market pressures and also from demands of the students themselves. The effects produced by the globalization of the labor markets intensively demand MBAs that incorporate in their curricula international, intercultural and global dimensions in the learning, teaching and assessment processes (Leask 2015). This internationalized graduate education should be in line with a plural, diversified and globally integrated labor market (Simm \& Marvell 2017).

Specially during the 1990s, academy and organizations are concerned on internationalized business education (Ball \& McCulloch Jr. 1993). Studies have been carried out in different parts of the world with different subjects over the last decade about the relationship between globalization and the development of international skills at business school for improving professional performance in different countries like USA, Australia, Thailand, UK and Brazil (Stromquist 2007; Cresling 2008; Pimpa 2009, Ketikidis et al. 2014; Vasques \& Ruas 2012).

Killick (2015) considers the internationalization of schools as an answer to the challenges of globalization and, from the students' point of view, it is a changing process toward a broader vision of the world. The Department of Education of the USA published in November 2012 a paper indicating strategic objectives of that country to foment the development of global competencies for the American students (Middlehurst 2013). This document recognizes that the ability of communicate, appreciate and work with diverse perspectives and points of view contributes to raise the cohesion among different people in the sense of integrated solutions to problems and global questions.

The incorporation of this institutional perspective in the USA was influenced by the effects of the economic crises of 2008 (Hudzik 2010). The global consequences of the economic crises activated the perception of schools and labor market that the internationalization of students should go beyond teaching and learning. The more missions and different perspectives experienced by students in different higher education institutions all over the world, the more the possibilities of solving global problems with global/local solutions.

Clifford \& Montgomery (2014) and Killick (2015) highlight that the global citizen comes before the global student; a quite expressive issue today in Europe and United Kingdom. The authors mentioned that education should be guided by a holistic and integrative vision aiming at providing to the student interesting experiences at the working environment. However, the analyses are more linked to the curricula reform than the issues related to the entrance competencies of students in graduate courses.

In the analysis of an internationalized graduate business program, McCormick \& Stephen (2016) have proposed a comprehensive framework in their research, considering the following concepts: (1) graduate experience through the coursework and (2) learning through studying abroad as influencers (independent variables) and (3) global skills necessary to the workplace and (4) global mindset as outcomes (dependent variables).

We used these four constructs presented in McCormick \& Stephen (2016) as guidelines to explore the many other concepts underlying internationalization of higher education in business, as follows: internationalization of curriculum (Leask 2009; Clifford 2013), innovative pedagogic approaches (Simm \& Marvell 2017; Kenna 2017), intercultural, learning and personal experience (Gu 2009; Hudzik 2010; Lyones \& Gurholt 2017; Pereira et al. 2017), 
critical thinking (Scheunpflug 2011; Bourn 2014; Kenna 2017; Lehtomäki et al. 2017), cross cultural competence (Johnson et al. 2006; Griffith 2009), global thinking (Bourn 2014; Klein et al. 2014; McCormick \& Stephen 2016), the challenge of established knowledge (Clifford \& Montgomery 2014; Killick 2015), global perspective (Hanvey 1976; Klein et al. 2014), global connectedness (Lehtomäki et al. 2017), global citizenship (Nussbaum 2002; Clifford \& Montgomery 2014; Haigh 2014; Sherman 2017), global dimension (Bourn 2014) and worldmindedness (Béneker et al. 2013).

\section{Internationalization at Home}

The concept of internationalization at home is widely debated in the higher education literature (Crowther et al. 2000; Nilsson 2003; Eisenchlas \& Trevaskes 2003; Wächter 2003; Leask 2004; Kehm \& Tachler 2007; Beelen 2011; Beelen \& De Wit 2012; Knight 2013; Mak \& Barker 2013; Harrison 2015; Simm \& Marvell 2017). The main idea is related to the ability to incorporate in teaching an internationalized dimension. It means that the students may enjoy an MBA program with an international emphasis without having to go abroad.

Looking back into a recent past, the issue "internationalization at home" gained a special emphasis in the 1999 Forum of EAIE (European Association for International Education) when scholars as Bengt Nilsson (Crowler et al. 2000) questioned the validity of internationalization programs like ERASMUS (European Region Action Scheme for the Mobility of University Students), one of the most important initiatives launched in 1987. Even ten years after the launch of these programs, by 1999, the proportion of students in Europe with international experience in his/her academic background was only $10 \%$. A viable alternative for the $90 \%$ left could be getting those international skills at home in domestic higher education institutions. As argued by Nilsson (2003, p.1) internationalization at home should not be restricted to a small fraction of participants: "The basic idea has been to try to let the internationalization process embrace the whole university: all staff and all students- not only the $10 \%$ of the mobile students and a few professors".

Taking into account Wächter (2003, p.6) definition, internationalization at home (laH) is "any internationally related activity with the exception of outbound student and staff mobility", the construct laH can be formed by all possible activities conducted at the higher education institution with the intent of providing international academic background to students: the content of the course (curriculum) and all the subjects and disciplines considered, the interaction student-student (within the student network), student-teachers, and studentdevices, including all innovative pedagogic tools available, besides extra-curricular activities students can get involved. Therefore, laH is a multifaceted concept involving important sub dimensions. This way, Crowther et al. (2000), corroborated by Harrison (2015) understand that the international education experience can happen through interaction with international students, curriculum development and innovative pedagogic approaches.

The interaction the students might have in their home institution with international peers along the course duration provides one relevant aspect of laH: the contact with other cultures. These contacts open room for the development of the ability to deal with diversity. The development of intercultural skills is immersed in "international education", one of the four dimensions of internationalization presented by Middlehurst (2013): the other three dimensions are: international student mobility, transnational education, and global networks. The author highlights the importance of initiatives towards integration of cross-cultural knowledge and widening the understanding of diverse educational pedagogical practices. 
According to Nilsson (2003) and also supported by Clifford (2013), students leaving university should have open minds, generosity toward other people, accordingly behavior with other cultures, adequate communication with people from other religions, values and customs and self confidence when dealing with unfamiliar issues.

The internationalization of curriculum is a relevant and practical way to bring in the classroom an international perspective that could help in the preparation of the student to deal with global issues. That is an important sub dimension of laH once it can provide the necessary content that would contribute to the understanding by students of the international dynamic in which a certain academic area of interest is inserted. It is possible to identify new layers of dimensions or factors in this sub dimension. According to Leask (2009) the internationalization of the curriculum takes place by means of the incorporation of international and intercultural dimensions in its content. Clifford (2013) distinguishes in the internationalization of curriculum, components like global perspectives, inter or cross-cultural dialogue, and socially responsible citizenship. This author stresses that the comprehension of different countries enables students to understand better their own institutions and organizations with an international perspective. Also the cross-cultural point of view contributes the ability of seeing the world considering other peoples perspective. As stated by Leask (2009, p.211), referring to the internationalization of curriculum: "Ideally, students will be required, at various stages through their program of study, to work on tasks that are structured in such a way that they cannot be successfully completed without a meaningful exchange of cultural information".

How the teaching (pedagogic approaches) is delivered to the students is also a critical issue, especially if one considers all the possibilities and tools available through information and communication technologies (ICT). ICT has a central role in internationalization at home once it allows real time contact with the world abroad and also provides several didactic tools and instruments to make feasible most pedagogic activities foreseen for a course. Simm \& Marvell (2017) reinforce that resources and technologies should be used effectively in order to create global students, like joint curriculum development, distance learning, international field courses and placements. However, these authors call the attention for new styles of teaching besides content. Kenna (2017) goes further and stresses the role of learning over teaching once the former centered in the students' needs while the latter is concentrated on the teacher's necessities. According to the author the learning perspective gets the students to examine new ways and perspectives when dealing with a challenge. Table 1 depicts the measurement of the construct "internationalization at home" and its indicators.

Table 1 - Internationalization at Home: construct and indicators

\begin{tabular}{|c|l|l|l|}
\hline Construct & \multicolumn{1}{|c|}{ Indicators } & \multicolumn{1}{c|}{ Description } & \multicolumn{1}{c|}{ Authors } \\
\hline \multirow{2}{*}{$\begin{array}{c}\text { Internationalization } \\
\text { at Home }\end{array}$} & $\begin{array}{l}\text { Interaction with } \\
\text { students / } \\
\text { professors / staff }\end{array}$ & $\begin{array}{l}\text { The contacts students } \\
\text { maintain with international } \\
\text { visiting colleagues and } \\
\text { faculties }\end{array}$ & $\begin{array}{l}\text { Middlehurst (2013); } \\
\text { Nilsson (2003); } \\
\text { Clifford (2013) }\end{array}$ \\
\cline { 2 - 4 } & $\begin{array}{l}\text { Internationalization } \\
\text { of curriculum }\end{array}$ & $\begin{array}{l}\text { All the content inside the } \\
\text { structure of an } \\
\text { international course }\end{array}$ & $\begin{array}{l}\text { Leask (2009); Clifford } \\
\text { (2013); }\end{array}$ \\
\cline { 2 - 4 } & $\begin{array}{l}\text { Innovative } \\
\text { pedagogic } \\
\text { approaches }\end{array}$ & $\begin{array}{l}\text { The teaching and its } \\
\text { tools, including innovative } \\
\text { didactic technologies }\end{array}$ & $\begin{array}{l}\text { Simm \& Marvell } \\
\text { (2017); Kenna (2017) }\end{array}$ \\
\hline
\end{tabular}

Source: Authors 


\section{Experience Abroad - Mobility}

The international experience abroad, i.e. the one which involves the mobilization of the student leaving his home country and going to get a degree in a foreign educational institution, is the most traditional way of seeing internationalization of higher education. This is confirmed by Simm \& Marvell (2017, p. 468): "Traditionally, internationalization of the curriculum has been associated with outbound mobility of students and staff".

The idea of a journey as an educational experience which outcomes might be transformative can be traced back in the Greek myths (Lyones \& Gurholt 2017). In those journeys the protagonist goes to a "strange" place as a visitor of other and people could gain "treasures" (lessons). According to Lyones \& Gurholt (2017) the concept of journey as an experience of education re-emerged in England as the Grand Tour (Gross 2008), when young and wealthy people, sons and daughters of the elite took those trips with the aim of knowing arts, culture and history as rite of passage.

These journeys can be considered as an important intercultural experience as much as a personal experience (Lyones \& Gurholt 2017; Gu 2009; Pereira et al. 2017). All the difficulties encountered by the student traveler in the foreign academic environment can bring a lot of suffering and considerable amount of stress, which Gu (2009) identified as shocks of all sort: culture, learning, education, language and role shocks. Nevertheless, the effort is worth to be made: when successful the intercultural experience might be transformative for the protagonist's life. As stated by $\mathrm{Gu}$ (2009, p. 47), "One has to cross cultural boundaries to experience the development of their intercultural competence and awareness". The learning that comes with the journey abroad is worth mentioning. Lyones \& Gurholt $(2017$, p.12) assert that the new experience usually destabilizes existing knowledge: "people find new responses in new circumstances". As aforementioned by Hudzik (2010), the possibilities of dealing successfully with problems applying global or local solutions are directly and positively correlated with the quantity and quality of missions experienced by the student. Table 2 presents the construct "experience abroad" and its indicators.

Table 2 - Experience Abroad: construct and indicators

\begin{tabular}{|c|c|c|c|}
\hline Construct & Indicators & Description & Authors \\
\hline \multirow{2}{*}{ Experience Abroad } & $\begin{array}{l}\text { Intercultural and } \\
\text { Learning Experience }\end{array}$ & $\begin{array}{l}\text { The academic } \\
\text { learning acquired in } \\
\text { a foreign } \\
\text { environment }\end{array}$ & $\begin{array}{l}\text { Lyones \& Gurholt } \\
\text { (2017); Pereira et al. } \\
\text { (2017); Gu (2009); } \\
\text { Hudzik (2010) }\end{array}$ \\
\hline & Personal Experience & $\begin{array}{l}\text { The personal } \\
\text { challenges faced by } \\
\text { the students when } \\
\text { studying abroad }\end{array}$ & $\begin{array}{l}\text { Lyones \& Gurholt } \\
\text { (2017); Pereira et al. } \\
\text { (2017); Gu (2009); } \\
\text { Hudzik (2010) }\end{array}$ \\
\hline
\end{tabular}

Source: Authors

In emerging countries like Brazil, the experience abroad also has its pros and cons. Pereira et al. (2017) reported the experiences of Brazilian students abroad and African students in Brazil. Although the African students enjoyed very much the academic journey and perceived it as personal development and represented opportunities in many ways, they had to face a kind of silent prejudice. The authors presented in short that the experience abroad was related 
to intercultural academic opportunities, allowed personal development, provided cultural enhancement and help identifying new working possibilities.

Taking into account that the two concepts "Internationalization at Home" and "Experience Abroad" have many points in common, like studying international business subjects and disciplines in the student home country or abroad, a first hypothesis is proposed:

\section{H1: There is a positive correlation between the international learning a student acquires in a MBA course at home (Internationalization at Home) and the international experience a student acquires abroad (Experience Abroad).}

\section{Global Skills}

Global Skills in the context of international higher education are those competences the professional must acquire to become able to deal successfully in a global business environment. After an international academic experience the student should shape abilities to develop critical analysis (Scheunpflug 2011; and Bourn 2014; Kenna 2017; Lehtomäki et al. 2017) in a global context, cultivate cross-cultural competence (Johnson et al. 2006; Griffith 2009), think globally (Bourn 2014; Klein et al. 2014; McCormick \& Stephen 2016) and learn how to challenge established knowledge and assumptions (Clifford \& Montgomery 2014; Killick 2015).

The capability of thinking in a critical way (critical thinking) has been for a long time an important requirement for all the players in the academy: students, professors, deans, managers, etc. (Kenna 2017). It is a trait linked to the falsifiability of Karl Popper, i.e., any truth is only acceptable the way it is until proof in contrary. Translating this into the business academic language for instance, a manager accepts a certain strategy or an innovative approach just until someone brings a better alternative to solve the problem. It is about an independent way of thinking unconnected from dogmas, doctrines or canons. According to Kenna (2017) critical thinking is a core issue in the internationalization of curriculum focusing in the development of global citizens able to critically think about the world. As exposed by Lehtomäki et al. (2017, p.2011) and Scheunpflug (2011) and Bourn (2014), the necessary competences in a globally connected world comprehend interpret own values and attitudes, reflect critically about knowledge and information, being able to analyze situations and perspectives, and concatenating local questions to global contexts.

Another relevant issue considering global skills is the faculty of dealing with a diverse cultural environment, known in the literature as cross cultural competence. As argued by White \& Griffith (1998) graduate business students should get in touch with different cultural issues and perspectives by means of language and cultural immersion, dealing with a diverse body of students and faculty as well. In the words of Johnson et al. (2006, p. 530): "Cross-cultural competence in international business is an individual's effectiveness in drawing upon a set of knowledge, skills, and personal attributes in order to work successfully with people from different national cultural backgrounds at home or abroad".

To think globally could also be considered another dimension of global skills. It is related to the capacity of and competence to deal with the business diversity of a global environment, taking into account the complex interdependence and connections typical of an international business logic. As posited by Klein et al. (2014, p.2), "A learning outcome of 'thinking globally' involves not only appreciating and understanding different international conditions but also considering these connections and deciding actions based on this broader perspective". As 
exposed by McCormick \& Stephen (2016) there is a strong pressure on graduate business schools to develop managers able to feel confident when heading business in different parts of the world.

Global skills are also associated to the competence of challenging establishment, i.e., the ability to confront traditional beliefs and long term assumptions taken as truth by the people involved. It takes a lot of energy to face all the opposition these situations usually produce. Status quo is naturally defended by those who helped in the construction of it. Simm \& Marvell (2017), Clifford \& Montgomery (2014) and Killick (2015) argue about the importance for students and professionals to challenge traditional views and confront dominant perspectives through the development of new ways of thinking. Table 3 shows the construct "Global Skills" and its indicators.

Table 3 - Global Skills: construct and indicators

\begin{tabular}{|c|c|c|c|}
\hline Construct & Indicators & Description & Authors \\
\hline \multirow{4}{*}{ Global Skills } & $\begin{array}{l}\text { Critical } \\
\text { Thinking }\end{array}$ & $\begin{array}{l}\text { The ability to think in an } \\
\text { independent and critical way }\end{array}$ & $\begin{array}{l}\text { Scheunpflug 2011; } \\
\text { Bourn 2014; Kenna } \\
2017 \text {; Lehtomäki et al. } \\
2017\end{array}$ \\
\hline & $\begin{array}{l}\text { Cross Cultural } \\
\text { Competence }\end{array}$ & $\begin{array}{l}\text { The competence to deal with a } \\
\text { diverse cultural environment }\end{array}$ & $\begin{array}{l}\text { Johnson et al. 2006; } \\
\text { Griffith } 2009\end{array}$ \\
\hline & Think Globally & $\begin{array}{l}\text { The capacity to deal with the } \\
\text { business diversity in a globalized } \\
\text { and interdependent world }\end{array}$ & $\begin{array}{l}\text { Bourn 2014; Klein et } \\
\text { al. 2014; McCormick \& } \\
\text { Stephen } 2016\end{array}$ \\
\hline & $\begin{array}{l}\text { Challenge } \\
\text { Established } \\
\text { Knowledge }\end{array}$ & $\begin{array}{l}\text { The faculty to confront traditional } \\
\text { beliefs and accepted assumptions }\end{array}$ & $\begin{array}{l}\text { Clifford \& Montgomery } \\
\text { 2014; Killick } 2015\end{array}$ \\
\hline
\end{tabular}

Source: Authors

Considering that "Global Skills", understood as the necessary abilities the student must acquire to face successfully the international business challenges, are the desired outcomes of a MBA course with international emphasis, and also considering the dynamics of higher education approached in this text about the concepts of internationalization at home and experience abroad, two hypotheses are proposed:

H2: The international learning a student acquires in a MBA course at home (Internationalization at Home) influences directly her/his skills (Global Skills) to deal successfully with business in an international context.

H3: The international experience a student acquires abroad (Experience Abroad) during a MBA course influences directly her/his skills (Global Skills) to deal successfully with business in an international context.

\section{Global Mindset}

The idea of global mindset is related to the consciousness someone may develop about how this person perceive herself or himself as a student, professional or a human being in the context of the whole world. It is associated to what this person thinks and does and its interactions and consequences considering the international environment around. In the academic literature, global mindset is linked to the concepts of global perspective (Hanvey 
1976, Klein et al. 2014), global connectedness (Bourn 2014; Lehtomäki et al. 2017), global citizenship (Nussbaum 2002; Clifford \& Montgomery 2014; Haigh 2014; Sherman 2017), global dimension (Bourn 2014) and world-mindedness (Béneker et al. 2013).

A pioneer work aiming at articulating the notion of global conscience in education was developed by Hanvey (1976) in the 1970's and updated by Klein et al. (2014). The original idea of Hanvey was to highlight to the American schoolteachers how the students could find a better way to think about themselves, about the nation, the themes they study, trying to provide the school content a more global context. According to Hanvey (1976), the objective of teaching in a global perspective was directly related to the maximization of five dimensions in every individual, considering her or his dispositions: (1) perspective consciousness: the recognition that someone has a particular view of the world which is not necessarily universal; (2) state of the planet: conscience of the conditions of the world and development, taking into account emergent conditions and trends; (3) cross-cultural awareness: conscience about the diversity of ideas and practices in vogue around the world in human societies; (4) knowledge of global dynamics: some comprehension of key traits and mechanism about how the world functions as a system; (5) awareness of human choices: a conscience of the problems of choice faced by individuals, nations and the human species and knowledge about how the global system expands. It is worth to say that this concept of Hanvey considers simultaneously the ideas of global skills (practical readiness to work in a global environment) and global mindset (a conscience of the self inserted in the world).

The higher education institutions on the way to prepare global citizens for a future of uncertainty are dealing with an ever more interconnected world, where disciplinary boundaries, subject contents and local contexts are no longer corresponding to the necessities of individuals, employers and societies (Lehtomäki et al. 2017). This takes to the concept of global connectedness which is related to the learning about the others, learning about the self, review of assumptions, reassesment of familiar issues and that "the relativeness of problems and global connection not only brings greater awareness but raises new questions" (Lehtomäki et al. 2017, p. 2022).

Another relevant dimension linked to global mindset is the concept of global citizenship which is related to the conscience that someone develop taking into account herself or himself having the whole world as a reference. One of the most cited definition (Clifford \& Montgomery 2014; Haigh 2014; Sherman 2017) was made by Nussbaum (2002), for whom global citizenship is formed by (1) the capacity to criticize one's own tradition; (2) think as a citizen of the world; and (3) be able to see the world with the other's eyes. In short, global citizen would be associated to the possibility of an ordinary local citizen to review his own status, incorporating a wider context and becoming global.

In line with the concept of global mindset is the term "global dimension" proposed by the Department of Education and Skills in the United Kingdom (Bourn 2014), which central focus is the promotion of learning in a world of interdependencies, the approach of similarities of people in the globe and the belief in a fairer and sustainable world. The term is linked to: global citizenship, sustainable development, social justice, diversity, values and perceptions, interdependence, conflict resolution and human rights.

Also associated with the idea of global mindset is the construct world-mindedness which is related to the questions about how someone sees herself or himself and their relation to the whole world. The term world-mindedness was a main issue on the research of Sampson and Smith (1957), cited in Béneker et al. (2013), who developed a scale in the 1950's 
compounded of eight dimensions: religion, immigration, government, economics, patriotism, race, education and war. Hett (1993) also constructed a similar measure comprehending the factors: responsibility, cultural pluralism, efficacy, global centrism and interconnectedness. Based on the work of Sampson and Smith (1957) and Hett (1993), Béneker et al., (2013, p.324) updated the concept and produced a new scale of world-mindedness, with which the authors could identify and present as "world-minded the individual who favors a world-view of the problems of humanity, whose primary reference group is mankind, rather than American, English, Chinese.". Table 4 depicts the construct "Global Mindset" and its indicators.

Table 4 - Global Mindset: construct and indicators

\begin{tabular}{|l|l|l|l|}
\hline Construct & \multicolumn{1}{|c|}{ Indicators } & \multicolumn{1}{|c|}{ Description } & \multicolumn{1}{c|}{ Authors } \\
\hline & $\begin{array}{l}\text { Global } \\
\text { Perspective }\end{array}$ & $\begin{array}{l}\text { perspective consciousness, } \\
\text { cross-cultural awareness, global } \\
\text { dynamics, awareness of human } \\
\text { choices }\end{array}$ & $\begin{array}{l}\text { Hanvey 1976; Klein et al. } \\
2014\end{array}$ \\
\cline { 2 - 5 } & $\begin{array}{l}\text { Global } \\
\text { Connectedness }\end{array}$ & $\begin{array}{l}\text { blurring disciplinary boundaries, } \\
\text { subject contents and local } \\
\text { contexts }\end{array}$ & $\begin{array}{l}\text { Bourn 2014; Lehtomäki } \\
\text { et al. 2017 }\end{array}$ \\
\cline { 2 - 5 } Mindset & $\begin{array}{l}\text { Global } \\
\text { Citizenship }\end{array}$ & $\begin{array}{l}\text { capacity to criticize one's } \\
\text { tradition, think as a citizen of the } \\
\text { world, see the world with the } \\
\text { other's eyes }\end{array}$ & $\begin{array}{l}\text { Nussbaum 2002; Clifford } \\
\text { \& Montgomery 2014; } \\
\text { 2017 }\end{array}$ \\
\cline { 2 - 5 } & $\begin{array}{l}\text { Global citizenship, sustainable } \\
\text { Global } \\
\text { Dimension }\end{array}$ & $\begin{array}{l}\text { development, social justice, } \\
\text { diversity, values and } \\
\text { perceptions, interdependence, } \\
\text { conflict resolution, human rights }\end{array}$ & Bourn 2014 \\
\cline { 2 - 5 } & $\begin{array}{l}\text { how someone sees herself or } \\
\text { himself and their relation to the } \\
\text { world }\end{array}$ & Béneker et al. 2013 \\
\cline { 2 - 5 } & Mindedness & &
\end{tabular}

Source: Authors

As summarized in Table 4, the concept of "Global Mindset", - understood as a conscience someone may develop about herself/himself (student, professional, citizen or human being) considering the whole world as the context -, can be influenced by an international academic formation be it originated at home (internationalization at home) or acquired in other countries (experience abroad); this way, another two hypotheses are proposed:

H4: The international learning a student acquires in a MBA course at home (Internationalization at Home) influences directly the development of a conscience (Global Mindset) about herself/himself in the context of the whole world.

H5: The international experience a student acquires abroad (Experience Abroad) during a MBA course influences directly the development of a conscience (Global Mindset) about herself/himself in the context of the whole world.

It is also hypothesized in this paper that the more global skills a student acquire, i.e., the more abilities and competences a student acquire to run an international business, the more 
predisposed this student is to develop a global conscience (global mindset) about herself/himself in the context of the whole world. Then come the next hypothesis:

H6: The more Global Skills the student acquire, the more susceptible she/he is to develop a Global Mindset.

\section{Proposed Model}

The proposed model is depicted in Figure 1. As mentioned before the main idea is to evaluate how much internationalized the student can be after taking a MBA course. The logical permeating the model is to do an assessment based on the concepts previously explored in the literature: internationalization at home (international learning in a domestic MBA course) experience abroad (international learning in another country than the home one), global skills (abilities acquired to deal successfully in a international business environment) and global mindset (conscience someone develop about world).

The assumptions about the relationship among these four latent variables presuppose the independent ones (influencers), - internationalization at home and experience abroad -, exert influence on the dependents (outcomes) global skills and global mindset. It is in the fundamentals of the model that besides the actual and evident experience abroad, a student can also acquire international skills in her/his home country university through interaction with foreign students and faculties, adoption of a comprehensive curriculum and through contact with innovative teaching methods. Nevertheless not only skills are expected as outcomes of a higher education experience in business, but also the formation of a mindset through which the student starts seeing the world with the eyes of a global and interconnected citizen.

Also to be considered are the possible influences of certain characteristics of the students in future samples, what in methodology is called moderator variables. McCormick \& Stephen (2016), in which research this paper got inspiration, used as a moderator the occupation of the respondent, i.e., if the student has or not worked for a multinational company. The very fact that someone is employed in a firm organized according to international business standards can be a relevant source of influence on the skills acquired. And if this condition, as a multinational employee, includes trips abroad with experience in the foreign unit, then expectations of influence grow even higher. It is reasonable to infer that any non academic experience abroad (participation in international events and congresses, short term courses, even touristic trips) might be quite influential in the formation of a global mindset for instance. Another important moderator could be how intense is the respondent connected to and/or involved in international issues through information and communication technology (ICT) devices. The internet and related technologies themselves have provided several possibilities for the internationalization process be it academic or not. 
Figure 1 - Proposed Model

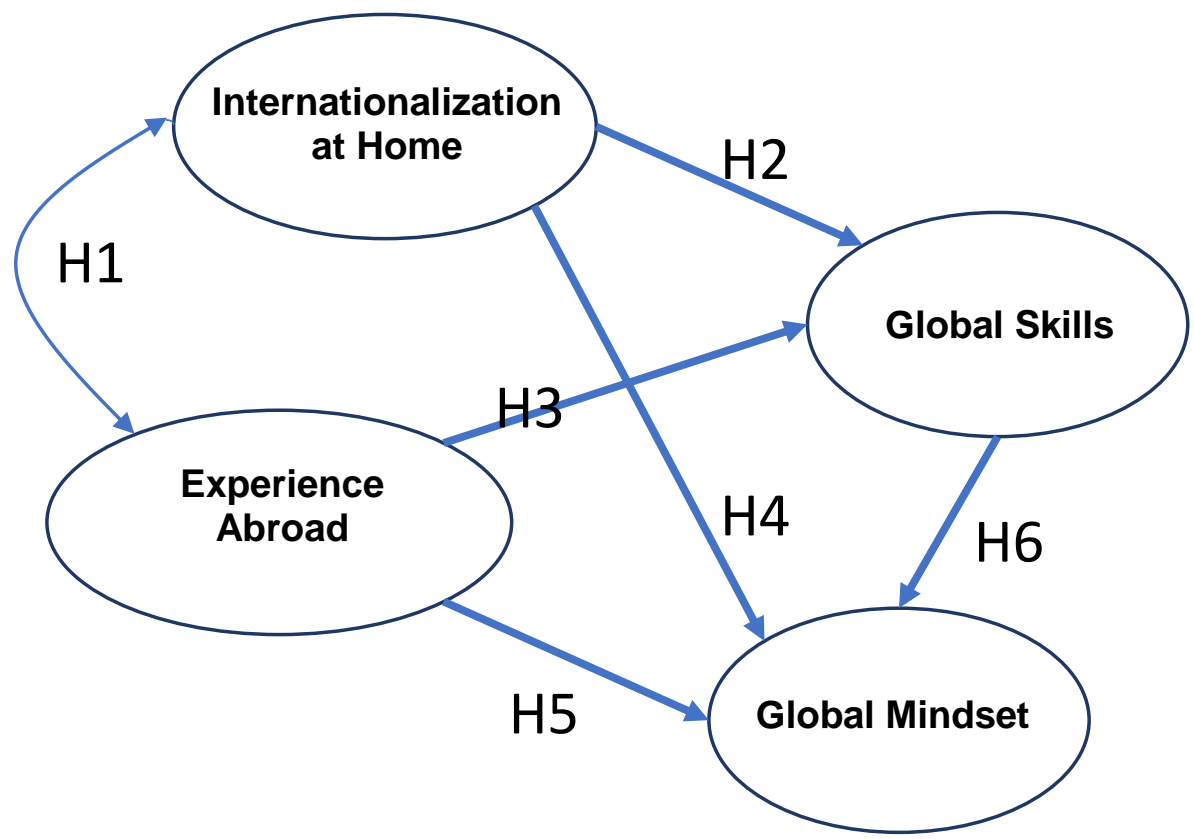

Source: Authors

As already mentioned, the proposed model was based on the work of McCormick \& Stephen (2016): the four constructs displayed in Figure 1 keep a general resemblance in meaning with the research framework developed by those authors. However, we went a step further in the sense that each of the four main concepts were explored in the investigated literature, so that underlying dimensions/facets were unlocked and consequently they were assumed as multidimensional constructs as shown in Table 1 (Internationalization at Home: construct and indicators), Table 2 (Experience Abroad: construct and indicators), Table 3 (Global Skills: construct and indicators) and Table 4 (Global Mindset: construct and indicators).

Besides that, another relevant difference from McCormick \& Stephen's are the proposed interrelationship among the concepts, where "internationalization at home" and "experience abroad" function as pure independent variables, influencing the other two dependents; "global skills" operates simultaneously as independent and dependent variable, and global mindset works as the final outcome, the main dependent construct of the model.

\section{Method}

For this study, a theoretical, exploratory and qualitative study was carried out. The relationships discussed in the theoretical approach allow us to understand that global mindset is composed by antecedent constructs, as well by its factors. The antecedents are characterized for Experience Abroad, Global Skills and Internationalization at Home. They are derived from some studies in the Education area and from experience. Based on this proposed conceptual model, the hypotheses were outlined and will be tested in the next phase of the research. 


\section{Concluding Remarks}

Considering all the complexities involved in the issue internationalization of a professional career, this paper had as objective to propose a model with the aim of assessing how global a graduate business student can be. To achieve this goal, a comprehensive examination of the literature was conducted focusing the basic dimensions underlying the internationalization concept in higher education.

As exposed along the text, the main factors identified as fundamental pillars in evaluating the internationalization level of business students were: (1) internationalization at home, understood as the possibility of getting international knowledge without having to move abroad; (2) experience abroad, involving academic and non academic explorations a student may undergo in other countries as an academic and/or a professional; (3) global skills, meaning all the knowledge a student may acquire to deal successfully with international business challenges; and (4) global mindset, signifying an international conscience about the planet in terms of culture, sustainability, justice, values and other issues related to a global citizenship. The expected relationships in the model are that constructs (1) and (2), internationalization at home and experienced abroad, influence the development of global skills (3), and also the formation of a global mindset (4).

It is also expected that some moderating variables will probably affect the relationships within the model, like the occurrence of previous professional experience abroad of the students, or the intimacy of these students with international networks through information technology communication (ICT) devices, or any other characteristic that might alter the balance of forces in the measurement scale, what can be included in the survey structure in order to be tested.

\section{References}

AACSB - Association to Advance Collegiate Schools of Business (2018). Disponível em https://www.aacsb.edul. Acesso em 19 set. 2018.

ANAMBA - Associação Nacional de MBA (2016). Padrões Comentados para Credenciamento e Recredenciamento de Cursos de MBA Padrão Global Base para Elaboração de Relatório de Autoavaliação (RAA). Disponível em <http://anamba.com.br/site2/files/2018/07/Novo-padraoglobal-comentado-jun16.pdf>. Acesso em 17 set. 2018.

ANAMBA \& NOZ Pesquisa e Inteligência (2017). Pesquisa MBAs 2017 - Mercado e Tendências. São Paulo, 2018, Available at: http://anamba.com.br/site2/files/2018/06/NOZ-Relatorio-MBAs-2017publicacao.pdf.

BALL, D \& MCCULOCH Jr, W 1993, 'The views of American Multinational CEOs on Internationalized Business Education for Prospective Employees', Journal of International Business Studies, vol. 24, no. 2, June, pp 383-391.

BALMANT, O 2018. Brasileiros buscam MBA com aulas no exterior: com experiência internacional, profissional pode conseguir mais facilmente uma promoção ou contratação desejada, $O$ Estado de São Paulo, January, 30th. Available at: https://educacao.estadao.com.br/noticias/geral,brasileiros-buscam-mba-com-aulas-noexterior, 70002170477.

BEELEN, J 2011, 'Internationalisation at Home in a Global Perspective: A Critical Survey of the $3^{\text {rd }}$ Global Survey Report of IAU', In: "Globalisation and Internationalisation of Higher Education" [online monograph], Revista de Universidad y Sociedad del Conocimiento (RUSC), vol. 8, no.2, pp. 249-264. UOC. 
BEELEN, J \& DE WIT, H 2012, 'Internationalisation Revisited: New Dimensions In The Internationalisation Of Higher Education', Centre For Applied Research On Economics And Management (CAREM).

BÉNEKER, T, TANI, S, UPHUES, R \& VAN DER VAART, R 2013, 'Young people's world-mindedness and the global dimension in their geography education: a comparative study of upper secondary school students' ideas in Finland, Germany and the Netherlands', International Research in Geographical and Environmental Education, vol. 22, no.4, pp. 322-336.

BOURN, D 2014, 'The theory and practice of global learning', Development Education Research Centre. Institute of Education. London International Development Centre, Research Paper N. 11.

BYRNE, J 2018, 'Why People Still Want An MBA Degree', Forbes. Available: https://www.forbes.com/sites/poetsandquants/2018/06/15/why-people-still-want-an-mbadegree/\#2850d71b288e.

CÂMARA DE EDUCAÇÃO SUPERIOR 2007, 'Resolução oํ 1/2007'. Available at: http://portal.mec.gov.br/cne/arquivos/pdf/rces001 07.pdf.

CÂMARA DE EDUCAÇÃO SUPERIOR 2018, 'Resolução no 1/2018', Available at: http://portal.mec.gov.br/docman/abril-2018-pdf/85591-rces001-18/file.

CLIFFORD, V 2013, 'The Elusive Concept of Internationalisation of the Curriculum. Definitions of internationalising the curriculum', Centre for Curriculum Internationalisation (CCl).

CLIFFORD, V \& MONTGOMERY, C 2015, 'Challenging conceptions of Western Higher Education and promoting graduates as global students', Higher Education Quarterly, vol. 68, no.1, pp. 28-45.

CROSLING, G. 2008, 'Internationalizing the curriculum: the implementation experience in a Faculty of Business and Economics', Journal of Higher Education Policy and Management, June. vol. 30, no.2, pp 107-121.

CROWTHER, P, JORIS, M, OTTEN, M, NILSSON, B, TEEKENS, H \& WÄCHTER, B 2000, 'Internationalisation at home: a position paper', Drukkerij Raddraaier, Amsterdam: European Association for International Education (EAIE).

CRUZ, JFP \& WOOD JR. T 2013, 'Para que Serve um MBA? GV Executivo, São Paulo, vol. 12, no. 2, Jul/Dec. Available at: https://rae.fgv.br/sites/rae.fgv.br/files/artigos/gv, pp. 332-351.

DANIEL, C. 1998, 'MBA: The First Century'. Cranbury, New Jersey: Associated University Presses.

DHANAWADE S \& SARANG, B 2012, 'Employability Skills of MBA Students at Entry Level: an Employers and Students Perspective', Sinhgad International Business Review, vol. 5, no.2, June.

EISENCHLAS, S \& TREVASKES, S 2003, 'Internationalisation at Home: Some Principles and Practices' In Liddicoat, Anthony J; Eisenchlas, S; Trevaskes, S 2003, 'Australian Perspectives on Internationalising Education', The National Languages and Literacy Institute of Australia.

ELLIOT, C \& ROBINSON, S 2011, 'MBA imaginaries: Projections of internationalization', Management Learning, vol. 0, no.0, pp. 1-25.

ESTADÃO. MBA Guide 2018. Available at http://publicacoes.estadao.com.br/ guiadomba/\#/home.

EUROPEAN COUNCIL: Council for European Union (EC/CEU) 2017, 'Celebrating 30 years of the Erasmus Programme', Available at: https://www.consilium.europa.eu/en/documentspublications/library/library-blog/posts/celebrating-30-years-of-the-erasmus-programme,

GROSS, M 2008, 'Lessons From the Frugal Grand Tour', Frugal Traveler. New York Times. Archived from the original on September 29.

GROVE, WA \& HUSSEY, A 2014, 'Returns to MBA quality: Pecuniary and non-pecuniary returns to peers, faculty and institution quality', Labour Economics, vol. 26, pp. 43-54. 
GU, Q 2009, 'Maturity and interculturality: Chinese students' experiences in UK higher education', European Journal of Education, vol. 44, no.1, Part I.

HAIGH, M 2014, 'From Internationalisation to Education for Global Citizenship: a Multi-Layered History', Higher Education Quarterly, vol. 68, no.1, January, pp. 6-27.

HANVEY, RG 1976, 'An attainable global perspective', New York, NY: American Forum for Global Education.

HARRISON, N 2015, 'Practice, problems and power in internationalization at home: critical reflections on recent research evidence', Teaching in Higher Education, vol. 20, no.4, pp. 412-430.

HAY, A \& HODGKINSON, M 2006, 'Exploring MBA career success', Career Development International, vol. 1, no.2, pp. 108-124.

HERRINGTON, J 2010, 'MBA, past, present and future', Academy of Educational Leadership Journal, vol. 14 , no.1.

HETT, EJ 1993, 'The development of an instrument to measure global-mindedness', Doctoral dissertation, University of San Diego, San Diego, Ca.

HUDZIK, J 2010, ‘Reshaping International Education', International Educator. May/Jun.

KEHM, BM \& TEICHLER, U 2007, 'Research on Internationalisation in Higher Education', Journal of Studies in International Education, vol. 11, no.3/4, Fall/Winter, pp. 260-273.

JOHNSON, JP \& LENARTOWICZ, T; Apud, SALVADOR. 2006, 'Cross-cultural competence in international business: toward a definition and a model', Journal of International Business Studies, vol. 37, pp. 525-543.

KENNA, T 2017, 'Teaching and learning global urban geography: an international learning-centred approach', Journal of Geography in Higher Education, vol. 41, no. 1, pp. 39-55.

KETIKIDIS, PH, VERVERIDIS \& Y, KEFALAS, P 2014, 'The Case of the University of Sheffield (TUOS) International Faculty, CITY College: An example of an entrepreneurial model for internationalisation of Higher Education'. In Meerman, A \& Kliewe, T (Eds.), UIIN Good Practice Series: Fostering University-Industry Relationships, Entrepreneurial Universities and Collaborative Innovation.

KILLICK, D 2015, 'Internationalization and the Academic Developer', Educational Developments, vol. 16 , no.3.

KLEIN, P, PAWSON, E, SOLEM, M \& RAY, W 2014, 'Geography education for An attainable Perspective', Journal of Geography in Higher Education, vol. 38, no. 1, pp. 17-27.

KNIGHT, J 2013, 'The changing landscape of higher education internationalisation - for better or worse? Perspectives', Policy and Practice in Higher Education, vol. 17, no.3, pp. 84-90.

LEASK, B 2004, 'Transnational Education and Intercultural Learning:Reconstructing the Offshore Teaching Team to Enhance Internationalisation', Proceedings of the Australian Universities Quality Forum.

LEASK, B 2009, 'Using Formal and Informal Curricula to Improve Interactions Between Home and International Students', Journal of Studies in International Education, vol. 13, no.2, pp. 205-221.

LEASK, B 2015, Internationalizing the curriculum, London: Routledge, 2015

LEHTOMÄKI, E, MOATEB, J \& POSTI-AHOKASC, H 2016, 'Global connectedness in higher education: student voices on the value of cross-cultural learning dialogue', Studies in Higher Education, vol. 41, no.11, pp. 2011-2027.

LEO, J 2010, 'Reorienting teacher education to address sustainable development: guidelines and tools: education for intercultural understanding', Unesco: Bangkok, Thailand. 
LOYNES, C \& GURHOLT, KP 2017, 'The journey as a trascultural experience for international students', Journal of Geography in Higher Education, vol. 41, no.4, pp. 532-548.

MAK, AS \& BARKER, MC 2013, 'Internationalisation at home: Enhancing intercultural capabilities of business and health teachers, students and curricula', Final Report. Lead institution: University of Canberra, Partner institution: Griffith University.

McCORMICK, M \& STEPHEN, S 2016, 'Are Graduate Business Students Ready for the Global Business Environment?', Journal of Higher Education Theory and Practice, vol. 16, no.5.

MIDDLEHURST, R 2013, 'Shifiting Patterns of International Higher Education", Change. September/October.

NILSSON, B 2003, 'Internationalisation at Home From a Swedish Perspective: The Case of Malmö', Journal of Studies in International Education, vol. 7, no.1, Spring, pp. 27-40.

NUSSBAUM, M 2002, 'Education for citizenship in an era of global connection', Studies in Philosophy and Education, 21, pp. 289-303.

OZBILGIN, M, KUSKU, F \& ERDOGMUS, N 2004, 'Explaining influences on career 'choice': the case of MBA students in comparative perspective', International Journal of Human Resource Management, vol.16, no.11, November, pp. 2000-2028.

PEREIRA, EMA, HEINZLE, MRS \& PINTO, MM 2017, 'Internationalization in higher education and student mobility: the going and coming of students', Espaço Pedagógico, vol. 24, no.1, pp.35-49.

PIMPA, N 2009, 'Learning problems in transnational business education and training: the case of the MBA in Thailand', International Journal of Training and Development;. vol.13, no.4.

PORTAL MEC 2018, 'Lato Senso - Saiba Mais', Available at: http://portal.mec.gov.br/posgraduacao/pos-lato-sensu.

SABBAG, R 2017, 'De olho em resultados, estudantes optam por pós-graduação mais curta', Gazeta do Povo, February, 1st. Available at: https://www.gazetadopovo.com.br/especialpatrocinado/uninter/de-olho-em-resultados-estudantes-optam-por-pos-graduacao-mais-curtaf4s25z488qnjprxj346chemsc/.

SARFATI, G \& ANDREASSI, T 2011, 'A internacionalização dos Cursos de Graduação em Administração de Empresas no Brasil', $X X X V$ Encontro da ANPAD, Rio de Janeiro (RJ), 4 a 7 de setembro.

SHARKEY, T \& BEEMAN D 2008, 'On the edge of hypercompetition in higher education: the case of the MBA', On the Horizon, vol. 16, no.3, pp.143-151.

SIMM, D \& MARVELL, A 2017, 'Creating global students: opportunities, challenges and experiences of internationalizing the Geography curriculum in Higher Education', Journal of Geography in Higher Education, vol. 41, no.4.

SILVA, PTM \& GODOY, AS 2016, 'MBA - O que alunos e ex-alunos pensam a repeito do curso realizado, seu aprendizado e do impacto em suas carreiras', Revista GUAL Florianópolis, vol. 9, no.3, Set 2016.

SHERMAN, P 2017, 'Why the world needs more global citizens', The Canadian Press, 09/29. Available at $\quad$ https: //ezproxy.uu.edu/login?url=http:// search.ebscohost.com/login. aspx?direct=true\&db=n5h\&AN=MY0152561734317\&site=ehost-live;

SPIRO, J 2014, 'Learning interconnectedness: internationalization through engagement with one another', Higher Education Quarterly. vol. 68, no.1, January, pp. 65-84.

STATISTA. 2015, 'The Statistics Portal. MBA Applicants' Main Reasons for Pursuing an MBA worldwide in 2015', Available at: https://www.statista.com/statistics/240085/main-reasons-forapplying-for-an-mba/. 
SCHEUNPFLUG, A 2011, 'Global education and cross-cultural learning: A challenge for a researchbased approach to international teacher education', International Journal of Development Education and Global Learning, vol.3, no.3, pp.29-44.

STROMQUIST, N 2007, 'Internationalization as a response to globalization: radical shifts in university environments', Higher Education, January, vol. 53, no.1, pp. 81-105.

TAY, A 2001, 'Management's perception of MBA graduates in Malaysia', Journal of Management Development, vol. 20, no.3, pp. 258-274.

VASQUEZ, ACS \& RUAS, RL 2012, 'Executive MBA programs: what do students perceive as value for their practices?', Revista de Administração Contemporânea (RAC), Curitiba, vol. 16, no.2, Mar/Abr.

VELUDO-DE-OLIVEIRA, T \& Ikeda, A 2006, 'Valor em Serviços Educacionais', RAE Eletrônica, vol. 6, no.2, July-December.

WÄCHTER, B 2003, 'Internationalisation at home - the context', in CROWTHER, P.; JORIS, M.; OTTEN, M.; NILSSON, B.; TEEKENS, H. \& WÄCHTER; B. 2003, 'Internationalisation at Home: A Position Paper', European Association for International Education.

WHITE, DS \& GRIFFITH, DA 1998, 'Graduate International Business Education in the United States Comparisons and Suggestions', International Perspectives, November/December, vol. 74, no.2, pp. 103-115.

WOOD JR., T \& PAULA, APP 2006, 'O Fenômeno dos MPAs Brasileiros: Hibridismo, Diversidade e Tensões', Revista de Administração de Empresas - era, São Paulo, vol. 4, no. 25, May/Jun.

ZAREMBA, J 2016, 'Criado nos EUA, conceito de MBA foi 'tropicalizado' e serve para quase tudo'. Folha de Sao Paulo, October, 27th. Available at: https://www1.folha.uol.com.br/sobretudo/carreiras/2016/10/1826655-conceito-de-mba-criadonos-eua-foi-tropicalizado-e-serve-para-quase-tudo.shtml. 